Journal of Food Technology 9 (2): 57-60, 2011

ISSN: $1684-8462$

(C) Medwell Journals, 2011

\title{
Physicochemical Properties of Some Traditional Vegetablesin Cote d'Ivoire: Seeds of Beilschmiedia mannii (Lauraceae), Seeds of Irvingia gabonensis (Irvingiaceae) and Mushroom Volvariella volvaceae
}

\author{
Sahore Drogba Alexis, Kouame Marie and Nemlin Gnopo \\ UTR of Foods Sciences and Technologies, University of Abobo-Adjamé, \\ Abobo, Adjamé, Abidjan (Cote D'Ivoire)
}

\begin{abstract}
Samples of fresh mushrooms Volvariella volvaceae, dry seeds of Irvingia gabonensis (Irvingiaceae) and dry seeds of Beilschmiedia mannii (Lauraceae), three traditional vegetables found on the market in Abidjan were studied in relation to their nutrients compositions (water, ash, protein, fat, carbohydrates, energy value) and minerals $(\mathrm{Ca}, \mathrm{Na}, \mathrm{K}, \mathrm{Mg}, \mathrm{Fe})$. The results show that the mushroom Volvariella volvaceae is characterized by a high water content $(81 \pm 0.53 \%)$, high carbohydrate content $(79.44 \pm 0.24 \% \mathrm{dm})$ and protein content $(17 \pm 0.04 \% \mathrm{dm})$ very significant. Mineral composition contains more $\mathrm{Na}(1.880 \pm 0.02 \% \mathrm{dm})$ and $\mathrm{K}(1.260 \pm 0.12 \%$ $\mathrm{dm})$. Seed of Irvingia gabonensis is rich in lipid $(63.61 \pm 0.70 \% \mathrm{~ms})$ but it also contains appreciable levels of carbohydrates $(23.25 \pm 0.17 \% \mathrm{~ms})$, protein $(7.23 \pm 0.80 \% \mathrm{DM})$ and mineral matter $(5.91 \pm 0.30 \% \mathrm{dm})$. These seeds of Irvingia gabonensis contain more K $(0.678 \pm 0.01 \% \mathrm{~ms})$ and $\mathrm{Ca}(0.452 \pm 0.09 \% \mathrm{~ms})$. Seed of Beilschmiedia mannii isrich in carbohydrates $(92.08 \pm 1.20 \% \mathrm{~ms})$ and has a significant protein content $(7.16 \pm 0.11 \% \mathrm{~ms})$, its mineral composition contains more than $\mathrm{K}(0.872 \pm 0.05 \% \mathrm{~ms})$.
\end{abstract}

$\underline{\text { Key words: Traditional, mushroom, seeds, nutrient, minerals, vegetables }}$

\section{INTRODUCTION}

The word vegetable is any edible part of a plant, mushroom or algae which is not sweet to taste. Also the plants supplying the condiments and herbs are included under this name.

In Africa about 4000 plant species have the potential to produce food crops. African traditional or local vegetables are one part. They are more and more known for their importance in contributing to food security of millions of Africans in rural and urban areas (Rubaihayo, 2002). These are the vegetables that the rural African population produces for consumption as local foods. According Rubaihayo (2002) they are considered as traditional vegetables for at least two reasons:

- Although, some of these plants are cultivated, others are easily found and harvested in their natural habitat

- Many of these plants have been consumed for many generations, reflecting their importance in local culture

Three categories of meats contribute to food in tropical Africa. The staple foods that provide the bulk of the energy ration, accompaniment foods that modify the taste qualities and provide essential elements (minerals, vitamins, supplements protein) and booster foods that take a leading role in welds or famine. Vegetables are classified in the second category, namely that of accompaniment foods.

Traditional vegetables contribute significantly, though rarely acknowledged, the food security of rural and urban populations in many African countries. They have a very high nutritional value. They contain vitamin A, B and C, proteins and minerals such as iron, calcium, phosphorus, iodine and fluorine in varying amounts but adequate for health (Rubaihayo, 2002). Traditional vegetables bring to the populations who have at their disposal only some few meat or fish, necessary proteins.

The study focuses on the physicochemical characterization of three traditional vegetables found on the market in Abidjan. These are samples of mushroom Volvariella volvaceae, seeds of Beilschmiedia mannii and Irvingia gabonensis.

\section{MATERIALS AND METHODS}

For this study researchers used samples of traditional vegetables, fresh mushrooms Volvariella volvaceae, dry seeds of Irvingia gabonensis (Irvingiaceae) and dry seeds of Beilschmiedia mannii (Lauraceae), bought in Abidjan market (Cote d'Ivoire).

Corresponding Author: Sahore Drogba Alexis, UTR of Foods Sciences and Technologies, University Of Abobo-Adjamé, Abobo, Adjamé, Abidjan (Cote d'Ivoire) 
Physicochemical analysis: The water content was determined by drying in an oven at $105^{\circ} \mathrm{C}$ for $24 \mathrm{~h}$ to constant weight (AOAC, 1980), the ash content was determined by incineration at $650^{\circ} \mathrm{C}$ muffle furnace ( $\mathrm{AOAC}, 1980$ ), the protein content was determined by the Kjeldahl method using as a conversion factor 6.25 , the lipid content was determined by Soxhlet extraction with ether; the total carbohydrate content was determined by difference according to the equation $\{100-(\%$ protein $+\%$ lipid $+\%$ ash $+\%$ water $)\}$. The energy value was calculated using the equation $\{(4 \times$ protein $)+(9 \times$ fat $)+(4 \times$ carbohydrate content) $\}$ (Atwater and Rosa, 1899); mineral elements Ca, $\mathrm{Na}, \mathrm{K}, \mathrm{Mg}, \mathrm{Fe}$ were determined with atomic absorption spectrophotometer varian 5 , after digestion of ash to hot into acid middle.

\section{RESULTS AND DISCUSSION}

The nutrient composition of the three traditional vegetables is shown in Table 1 . The contents are reported in percentage of dry matter.

The mushroom Volvariella volvaceae is a species of mushroom rich in water $(81.00 \pm 0.53 \%)$ and in carbohydrate $(79.44 \pm 0.24 \% \mathrm{dm})$, its protein contents $(17.01 \pm 0.04 \% \mathrm{dm})$ and fat content $(3.44 \pm 0.02 \% \mathrm{dm})$ are remarkable, its mineral content $(0.11 \pm 0.01 \% \mathrm{dm})$ remains scarce. its energy value $(397.93 \pm 4.82 \mathrm{cal} / 100)$ is appreciable.

Seeds of Irvingia gabonensis contain carbohydrates $(23.25 \pm 0.17 \% \mathrm{dm})$, protein $(7.23 \pm 0.80 \% \mathrm{dm})$ and ashes $(5.91 \pm 0.30 \% \mathrm{dm})$ with appreciable levels and a significant quantity of fat $(63.61 \pm 0.70 \% \mathrm{dm})$. The energy value $(707.68 \pm 3.19 \mathrm{cal} / 100)$ of these seeds is high.

Beilschmiedia mannii seeds contain a big quantity of carbohydrates $(92.08 \pm 1.20 \% \mathrm{dm})$, of average rates of protein $(7.16 \pm 0.11 \% \mathrm{dm})$, of ashes $(3.89 \pm 0.24 \% \mathrm{dm})$ and of a small quantity of lipids $(0.61 \pm 0.04 \% \mathrm{dm})$. The energy value $(379.61 \pm 1.90 \mathrm{cal} / 100)$ is appreciable.

The composition of mineral elements of traditional vegetables is shown in Table 2. Element contents are reported in percentage of dry matter. The mushroom
(Volvariella volvaceae) contains more $\mathrm{Na}(1.880 \pm 0.02 \%$ $\mathrm{dm}), \mathrm{K}(1.260 \pm 0.12 \% \mathrm{dm})$, slightly less Ca $(0.120 \pm 0.04 \%$ $\mathrm{dm}), \mathrm{Mg}(0.130 \pm 0.01 \% \mathrm{dm})$ and very little iron $(0.010 \pm 0.00 \% \mathrm{dm})$.

Irvingia gabonensis seeds contain more $\mathrm{K}$ $(0.678 \pm 0.01 \% \mathrm{dm}), \mathrm{Ca}(0.452 \pm 0.09 \% \mathrm{dm})$, slightly less $\mathrm{Mg}$ $(0.213 \pm 0.01 \% \mathrm{dm})$ and very little $\mathrm{Na}(0.061 \pm 0.00 \% \mathrm{dm}), \mathrm{Fe}$ $(0.012 \pm 0.00 \% \mathrm{dm})$.

Beilschmiedia mannii seeds contain more $\mathrm{K}$ $(0.872 \pm 0.05 \% \mathrm{dm})$, slightly less $\mathrm{Ca}(0.104 \pm 0.02 \% \mathrm{dm})$ and very little $\mathrm{Na}(0.061 \pm 0.01 \% \mathrm{dm}), \mathrm{Mg}(0.071 \pm 0.00 \% \mathrm{dm}), \mathrm{Fe}$ $(0.029 \pm 0.00 \% \mathrm{dm})$.

Mushroom Volvariella volvaceae: Mushroom Volvariella volvaceae is a species of fungus that has high carbohydrate content $(79.44 \pm 0.24 \% \mathrm{dm})$. This value is above that one given by Parent and Thoen (1977) for species Cantharellus cibalus (64\% dm) and Russula sp. $(55 \% \mathrm{dm})$ picked in D.R of Congo. And it approaches the value found by Azema in the inedible species polyporus sulfureus $(73 \% \mathrm{dm})$. The appreciable protein content $17 \pm 0.04 \% \mathrm{dm}$ is between those of mushrooms Cantharellus cibalus (15\% dm) and Russula sp. $(29 \% \mathrm{dm})$ that were given by Parent and Thoen (1977).

The rate of fat $3.44 \pm 0.02 \% \mathrm{dm}$, is lower than those of fungi Cantharellus cibalus $(6 \% \mathrm{dm})$ and Russula sp. $(6 \% \mathrm{dm})$ of Parent and Thoen (1977) and Lactarius phlebophyllum species $(9 \% \mathrm{dm})$ found by Harkonen et al. (1994).

Contrariwise, the species Clitopilus prunulus $(0.00 \% \mathrm{dm})$ and Fistulina hepatica $(0.06 \% \mathrm{dm})$ studied by Azema contain less fat. With $0.11 \pm 0.01 \% \mathrm{dm}$.

The rate of mineral matter is scarce, it is outside the range $1.76 \% \mathrm{dm}$ (Clitocybe gigantea) $34 \% \mathrm{dm}$ (Cortinarius praestans) of different fungi's contents studied by Azema.

The high value of water content $(81 \pm 0.53 \%)$ shows that the mushroom Volvariella volvaceae like all specimens with hat (50-90\%) according Azema is also rich

Table 1: Nutrients composition ( $\%$ of dry matters)

\begin{tabular}{|c|c|c|c|c|c|c|}
\hline \multirow[b]{2}{*}{ Samples } & \multicolumn{6}{|l|}{ Elements } \\
\hline & Water & Proteins & Lipids & Carbohydrates & Ashes & Energy (calories) \\
\hline Volvariella volvaceae & $81.00 \pm 0.53$ & $17.01 \pm 0.04$ & $3.44 \pm 0.02$ & $79.44 \pm 0.24$ & $0.11 \pm 0.010$ & $397.93 \pm 4.82$ \\
\hline Irvingia gabonensis & $4.97 \pm 0.50$ & $7.23 \pm 0.80$ & $63.61 \pm 0.70$ & $23.25 \pm 0.17$ & $5.91 \pm 0.30$ & $707.68 \pm 3.19$ \\
\hline Beilschmiedia mannii & $11.40 \pm 0.72$ & $7.16 \pm 0.11$ & $0.61 \pm 0.04$ & $92.08 \pm 1.20$ & $3.89 \pm 0.240$ & $379.61 \pm 1.90$ \\
\hline
\end{tabular}

The indicated values represent the average of three determinations $(n=3)$

Table 2: Mineral composition (\% dry matter)

\begin{tabular}{|c|c|c|c|c|c|}
\hline \multirow[b]{2}{*}{ Samples } & \multicolumn{5}{|l|}{ Elements } \\
\hline & $\mathrm{Ca}$ & $\mathrm{Na}$ & $\mathrm{K}$ & $\mathrm{Mg}$ & $\mathrm{Fe}$ \\
\hline Volvariella volvaceae & $0.120 \pm 0.04$ & $1.880 \pm 0.02$ & $1.260 \pm 0.12$ & $0.130 \pm 0.01$ & $0.010 \pm 0.00$ \\
\hline Irvingia gabonensis & $0.452 \pm 0.09$ & $0.061 \pm 0.00$ & $0.678 \pm 0.01$ & $0.213 \pm 0.01$ & $0.012 \pm 0.00$ \\
\hline Beilschmiedia mannii & $0.104 \pm 0.02$ & $0.061 \pm 0.01$ & $0.872 \pm 0.05$ & $0.071 \pm 0.00$ & $0.029 \pm 0.00$ \\
\hline
\end{tabular}

The indicated values represent the averages of three determinations $(n=3)$ 
in water. In conclusion, this mushroom is characterized by its high water content $(81 \pm 0.53 \%)$, its high carbohydrate content $(79.44 \pm 0.24 \% \mathrm{dm})$ and its protein content $(17 \pm 0.04 \% \mathrm{dm})$ appreciably.

Mushroom Volvariella volvaceae contains high concentrations of $\mathrm{Na}(1.880 \pm 0.02 \% \mathrm{dm})$ and $\mathrm{K}(1.260 \pm$ $0.12 \% \mathrm{dm}$ ). These values are higher than those of ears Fungus (Na: $0.985 \% \mathrm{~ms} ; \mathrm{K}: 0.310 \% \mathrm{dm}$ ). The contents of $\mathrm{Ca}(0.120 \pm 0.04 \% \mathrm{dm})$ and iron $(\mathrm{Fe})(0.010 \pm 0.00 \% \mathrm{dm})$ are lower than those of ears Fungus (Ca: $0.310 \% \mathrm{dm}$ ) (Fe: $0.042 \% \mathrm{dm}$ ).

Seeds of Irvingia gabonensis: Seeds of Irvingia gabonensis contain lots of fat $(63.61 \pm 0.70 \% \mathrm{dm})$. A value close to those found by Ekpe et al. (2007) $66.60 \pm 0.80 \% \mathrm{dm}$ and by Kouame and Gnahoua (2008) 65.84\% dm.

The protein content $(7.23 \pm 0.80 \% \mathrm{dm})$ is also significant. Its value lies between those given by Ekpe et al. (2007) 7.6\% dm and Women etal. (2006) 8.40\% $\mathrm{dm}$. But it remains below the rate of $5.83 \% \mathrm{dm}$ found by Kouame and Gnahoua (2008).

The total carbohydrate content $(23.25 \pm 0.17 \% \mathrm{dm})$ is also significant in this traditional vegetable. With a slightly higher rate of carbohydrate to that given by Womeni et al. (2006) $19.20 \% \mathrm{dm}$.

The seeds of Irvingia gabonensis have a remarkable mineral content $(5.91 \pm 0.30 \% \mathrm{dm})$. Its value is lower than that one found by Ekpe et al. (2007) $9.50 \pm 0.30 \%$ dm, it is above the data of Kouame and Gnahoua (2008) 2.31\% $\mathrm{dm}$ and of Womeni et al. (2006) $2.21 \% \mathrm{dm}$

The energy value $(707.68 \pm 3.19 \mathrm{ca} / / 100)$ of seeds of Irvingia gabonensis is remarkable. That could be explained by the relatively high levels of fat, protein and total carbohydrate. In conclusion we note that seeds Irvingia gabonensis are a vegetable rich in fat but contain levels of carbohydrates, protein and mineral matter equally remarkable.

Seeds of Irvingia gabonensis contain more $\mathrm{K}$ $(0.678 \pm 0.01 \% \mathrm{dm})$ and $\mathrm{Ca}(0.452 \pm 0.09 \% \mathrm{dm})$, a little less of $\mathrm{Mg}(0.213 \pm 0.01 \% \mathrm{dm})$, very little $\mathrm{Na}(0.061 \pm 0.00 \% \mathrm{dm})$ and $\mathrm{Fe}(0.012 \pm 0.00 \% \mathrm{dm})$. These different contents are in approximate proportion to those given by Kombou and Joseph (1984) related to the kernel of Irvingia gabonensis in Cameroon $\mathrm{Fe}: 0.06 \% \mathrm{dm}$; $\mathrm{Mg}: 0.63 \% \mathrm{dm}$; Ca: $0,60 \% \mathrm{dm}$.

Seeds of Beilschmiedia mannii: Seeds of Beilschmiedia mannii contain high level of carbohydrates $(92.08 \pm 1.20 \% \mathrm{dm})$. This value is slightly above that given by Leung et al. (1968) $88.76 \% \mathrm{dm}$.

The protein content $(7.16 \pm 0.11 \% \mathrm{dm})$ has a value between those found by Kouame and Gnahoua (2008) $6.67 \% \mathrm{dm}$ and by Leung et al. (1968) $8.92 \% \mathrm{dm}$. This vegetable has a low fat content $(0.61 \pm 0.04 \% \mathrm{dm})$, a lower result than that of Gnahoua and Kouame 2.04\% dm. But close to that given by Leung et al. (1968) $0.59 \% \mathrm{dm}$.

The rate of mineral matter $(3.89 \pm 0.24 \%)$ has a value less than that given by Gnahoua and Kouame $5.70 \% \mathrm{dm}$. The energy value $379.61 \pm 1.90 \mathrm{cal} / 100$ of this vegetable is also significant and is similar to that given by Leung et al. (1968) $389 \mathrm{cal} / 100$. We will note that the seeds Beilschmiedia mannii are a traditional vegetable rich in carbohydrates with a significantly protein content.

Seeds of Beilschmiedia mannii contain more $\mathrm{K}$ $(0.872 \pm 0.05 \% \mathrm{~ms})$, a little less $\mathrm{Ca}(0.104 \pm 0.02 \% \mathrm{dm})$, very little of $\mathrm{Mg}(0.071 \pm 0.00 \% \mathrm{dm}), \mathrm{Na}(0.061 \pm 0.01 \% \mathrm{dm})$ and $\mathrm{Fe}(0.029 \pm 0.00 \% \mathrm{dm})$.

Leung et al. (1968) gives a calcium content of the Beilschmiedia mannii seeds equal to Ca: $0.258 \% \mathrm{dm}$. A value greater than that found in the study Ca: $0.104 \pm 0.02 \% \mathrm{dm}$ ).

\section{CONCLUSION}

The mushroom Volvariella volvaceae is characterized by high water content, high carbohydrate content and significant protein content. This mushroom is relatively rich in $\mathrm{Na}$ and $\mathrm{K}$.

The seeds of irvingia gabonensis are rich in fat and contain a level of carbohydrates, protein and mineral matter equally remarkable. The seed of irvingia contains less $\mathrm{Na}$ and more $\mathrm{K}, \mathrm{Ca}, \mathrm{Mg}$. Beilschmiedia mannii seeds are a food rich in carbohydrates with significant protein content. The seed of Beilschmiedia contains less $\mathrm{Na}, \mathrm{Mg}$ $\mathrm{K}$ and $\mathrm{Ca}$.

In order to better know the nutritional value of these traditional vegetables, the study of nutrients and mineral elements should be completed by vitamins, amino acids and antinutritional factors.

\section{REFERENCES}

AOAC, 1980. Association of Official Analytical Chemist. Official Methods of Analysis. 11th Edn., Association of Official Analytical Chemist, Washington DC., USA.

Atwater, W.O. and E.B. Rosa, 1899. A new respiration calorimeter and experiments on the conservation of energy in the human body, II. Physical Rev., 9: $214-251$.

Ekpe, O.O., I.B. Umoh and O.U. Eka, 2007. Effect of a typical rural processing method on the proximate composition and amino acid profile of bush mango seeds (Irvingia gabonensis). Afr. J. Food Agric. Nutr. Dev., 7: 164-171. 
Harkonen, M., T. Saarimaki and I. Mwasumbi, 1994. Edible and poisonous mushroom of Tanzania. Afr. J. Mycol. Biotechnol., 2: 99-123.

Kouame, N.M.T. and G.M. Gnahoua, 2008. Spontaneous food trees and lianas of the semi deciduous forest zone (Center-West of Ivory Coast): Species encountered, plant parts consumed and food values. IUFRO International Conference on Traditional Forest Knowledge. Accra, 15-18 October 2008.

Leung, W.T.W., F. Busson and C. Jardin, 1968. Food Composition Table for use in Africa. FAO, Rome, Italy, pp: 306.
Parent, G. and D. Thoen, 1977. Food value of edible mushrooms from Upper-Shaba eegion. Econ. Bot., 31: 436-445.

Rubaihayo, E.B., 2002. The contribution of indigenous vegetables to household food security. IK Notes, 44: $1-4$.

Womeni, H.M., R. Ndjouenkeu, C. Kapseu, M.F. Tchouanguep, M. Parmentier and J. Fanni, 2006. Influence of drying techniques on the kinetics of almonds water loss and the oil quality of Irvingia gabonensis. Alimentary Biol. Processes, 3: 46-60. 